\begin{tabular}{c} 
International Journal of Engineering \& Technology, $7(3.21)(2018) 152-160$ \\
International Journal of Engineering \& Technology \\
SPC \\
Website: $\frac{w w w . s c i e n c e p u b c o . c o m / i n d e x . p h p / I J E T}{2 \text { Research paper }}$ \\
\hline
\end{tabular}

\title{
The Macroeconomic Determinants of Foreign Bank's Profitability in Malaysia
}

\author{
Pang Jiunn Yi ${ }^{1}$; Devinaga R $^{2}$; Yuen Yee Yen ${ }^{3}$; Suganthi ${ }^{4}$; Shalini ${ }^{5}$ \\ ${ }^{1,2,3,4,5}$ Faculty of Business, Multimedia University (Melaka) \\ *Corresponding author E-mail: devinaga.rasiah@mmu.edu.my
}

\begin{abstract}
The topic of this research paper is "The macroeconomic determinants of foreign bank's profitability in Malaysia. Panel data method were employed to analyze the cross sectional data and time series data collected from 2006 to 2015 from a sample of ten foreign banks in Malaysia. Measurement of profitability is based on Return on assets which is a function of the macroeconomic determinants; GDP, inflation rate and real interest rate. The overall finding of this research study shows that GDP, inflation rate and real interest rate are the determinants of foreign banks in Malaysia. Those determinants were found to be statistically related on profitability and all of them had a positive relationship towards the profitability of foreign banks in Malaysia.
\end{abstract}

Keywords: Profitability; Foreign Bank; Return on Assets; inflation rate: Consumption Expenditures,

\section{Introduction}

Currently, the financial institutions in Malaysia is divided into three major groups; banking system, non-bank financial intermediaries and financial markets. Banking system of Malaysia are includes of the commercial banks for both domestic and foreign banks, finance companies and the merchant banks. Moreover, with approximately $70 \%$ of the total assets of the financial system, banking system is the largest component in the financial system. Observing bank's profitability is vital as it provide basis to identify the market condition and aid in making adjustment and proper decision based on the uncertainty of shock event (1). This is because if the bank's performance is poor, it would definitely impact the economy as a whole.

Furthermore, foreign banks are started to participate in the domestic banking market and it had increased the competition in the banking system (2). This supports the view that presence of foreign bank lead to a rising competition and thus provide a larger competence in the local banking markets. The entry of the foreign banks puts the pressure on domestic banks and decrease their historical profits and high income. However, foreign bank entry also puts pressure on domestic banks to become more efficient, which helped them to reduce the costs, since the latter had the ability to modify or copy the modern banking techniques and practices (3). This research purpose is to determine the relationship between the macroeconomic determinants and profitability of foreign banks in Malaysia. In this research, ten foreign banks in Malaysia had been randomly selected to determine their profitability from the year 2011 to 2015. The ten selected foreign bank in Malaysia are OCBC Bank, UOB Bank, Citibank, HSBC Bank, Standard Chartered Bank, Bank of China (Malaysia) Berhad, Deutsche Bank (Malaysia) Berhad, J.P. Morgan Chade Bank Berhad, Royal Bank of Scotland and Bank of Tokyo Mitsubishi-UFJ.

\subsection{Problem Statement}

As stated earlier, foreign banks are started to participate in the domestic banking market and it had increased the competition in the banking system (2). In order for them to survive in this competitive banking market, both types of bank must provide unique services and products to differentiate them from others and attract more customers (1). Previously, there are three main issues statement that had been discussed in the theoretical literature, which were foreign banks would affect competition, influence the efficiency of domestic banks and had a significant effect on the stability of the domestic banking system (3). However, there is only limited empirical evidence to support on all these three statement. According to the previous studies (4-6), most of the researcher are focusing on the studies of both internal and external determinants of commercial bank. Therefore, this research would definitely conduct a more specific and focusing on the studies of macroeconomics determinants which would affect the bank's profitability. Moreover, previous research are more focusing in determine the profitability of commercial bank no matter in Malaysia or other countries.

Besides that, there is also some practical problem of the profitability of foreign bank exist currently. The previous researcher had found that the performance of some of the domestic banks were better than some of the foreign banks. There is a previous study about the Malaysian banks profitability for the period of year 2004 to 2008 , which shows that the domestic banks were more profitable than the foreign banks in Malaysia (7). Another research were showing about the domestic banks were more efficiently by comparing to the foreign banks (8). Therefore, other researcher would definitely wish and interesting to determine and understand about the main determinants that would affect the profitability of foreign bank. 


\subsection{Research Objectives}

To examine the relationship between annual real GDP growth rate Inflation Rate and interest rate on foreign bank's profitability in Malaysia.

This research would benefits for two majority groups, which are practitioners and other researchers. For the aspects of practitioner, bank manager would definitely had a more clearly and understanding about what improvement and adjustment should be made according to the changes of these three macroeconomic determinants in order to maximise the profitability of their bank.

This research is critical and important in the banking sector, especially for the foreign bank's operation and decision making. Although there are some of the researchers already conduct the similar research before, but they had study about both internal and external determinants, which are too general. Therefore, this research would definitely had a more specific and focusing on the studies of macroeconomics determinants which would affect the bank's profitability. Moreover, there are no any existing and related study in the area of foreign bank especially in Malaysia. Therefore, by carry out this specific topic in the foreign bank areas, this research would provide a better and more accurate result adding value for the existing knowledge in banking sector.

In this research project, ten foreign bank in Malaysia are randomly selected to determine their profitability, which the dependent variable of this study. In the time scope of year 2011 to year 2015, the independent variables in this research project are the macroeconomic determinants, which are annual GDP growth rate, annual inflation rate and real interest rates. Secondary data and sources were chosen to conduct this research.

\section{Literature Review}

\subsection{Dependent Variable}

\subsubsection{Bank's Profitability}

Bank Profitability is sensitive to macroeconomic conditions although the trend in the industry towards a greater geographic diversification (5). Profit is equal to revenue minus cost. This equation sounds simple and concise but misleading, as almost everyone who's analysed profitability in detail could attest (Waters, 2005). The primary desire of all the banks is to make profit continuously in order to sustain their position in the industry and had a relative competitive advantage by comparing to others(9)

\subsubsection{Foreign and Domestic Bank}

The Malaysian banking system could be categorized into three major types, which are commercial banks that includes both domestic and foreign banks, finance companies and also the merchant banks. Commercial banks are the most important players in the banking system as they are the major funds providers in the Malaysian banking system. According to (10) and (11) among others, the entry of the foreign bank could bring some potential benefits to the domestic bank in terms of higher and better resource allocation. Furthermore, the study of (10) had states that, domestic financial development, improve a country's access to international capital markets and enhance the quality of financial service in domestic bank can be foster through the entrance of foreign banks.

However, (12) found that the foreign bank entrance might cause some negative impact to the local banks in term of potential increase in costs. The study found that the domestic banks may need to increase their costs in order to compete with the foreign banks by improve in terms of advance technology, banking skills and management skills. In addition, (13) found that the entry of foreign banks had increase the risks expose to domestic banks. The intense competition with foreign bank would then reduce the earnings of domestic banks.

Some of the review on the bank efficiency found that the foreign banks possess a relatively lower efficiency by comparing to the domestic banks, especially in those developed countries $(14,15)$. However, compared to domestic banks in some developed countries, there are still some foreign banks are able to operate more efficiently (16). As the observed findings were ambiguous and indecisive, thus, this is the motive that encourage us to conduct this research study in order to determine the relationship between the macroeconomic determinants and the bank's profitability.

\subsubsection{Measurement of Profitability}

Return on assets (ROA) refers to the banks' after tax profit over the total assets, which means it is computed by dividing the net income over the total assets. (17). It had been selected as a measurement of the bank profitability by most of the previous researcher. According to the $(6,9,18)$ among others, the measurement that they used to determine the dependent variable in their research study is ROA. ROA is used to measures the profit earned per dollar of assets and reflect how well the bank manage to use their real investment resources to generate profits $(19,20)$. In addition, ROA is depends on the bank's policy decisions and the uncontrollable factors that related to the economy and government regulations (5). By comparing to ROE, ROA had taken into the consideration about the risks which derived from the leverage and is the key bank profitability ratio (21). However, ROA had a possible disadvantages is that the existence of the off-balance-sheet asset, which represent the important sources for all the banks, but are not considered in the calculation (22).

\subsection{Independent Variable}

\subsubsection{GDP}

Annual real GDP growth rate, which also known as the economic growth is referred to a measurement of the total economic activity, which is adjusted for inflation (4). A rapid economic growth would definitely had a significouldt increase the profitability for most of the countries around the world (6). According to the previous research on the relationship between the economic growth and the bank's profitability, GDP is expected a positive impact on the profitability of the bank because it is related to the supply and demand of the bank's deposits and loan $(23,24)$.

According to the research in Switzerland, (25) showed the results that the GDP growth rate is one of the most important macroeconomic determinants, which had a positive impacts on the bank's profitability. However, there is another research study found that the bank's profitability are not significant affect by the economic growth (26). Similarly, Petria, et al. (27) state that the GDP growth rate negatively affects the performance of banks. Contrarily, $(17,28)$ found that the macroeconomic policies that promote the stable output growth had affected the bank's profitability. This could be concluded that there is positive relationship between GDP and the bank's profitability.

Moreover, the results showed in the research illustrate that the economic growth had no impact on the bank's interest margin and profitability $(19,29)$. Thus, the conclusion of these studies were there were no any relationship between economic growth and bank's profitability. Another recent research from (30) found that the GDP growth rate had a negative impacts on the profitability of Nigerian banks. (9) on the other hand did an analysis and conclude that the economic growth are statistically significant on the profitability of commercial bank in Nigeria. Additionally, the research from (6) had developed the hypothesis of the external factors of banks had a positive impact on the profitability. This provides the evidence that the hypothesis is accepted and GDP growth rate had a positive impact on the profitability of the bank's in Pakistan. 
Furthermore, (21) found that the European bank's profitability are not significant affected by the real GDP per capita fluctuations, which the study had conducted to investigate the South Eastern European area over the year 1998 to the year 2002. As the matter of fact, the economic growth had multiple impacts among which are the increase in bank activity. Thus, the increase in customer deposits and the amount of loan granted would had a positive impact on the bank profitability (31). In addition, (32) found that the real GDP growth that use in this study had a positive impact on the European bank's performance. (18) had identified the macroeconomic factors of Chinese banking sector profitability and they found that there are linear relationship between the economic growth and the profitability of the banks in China.

\subsubsection{Personal Consumption Expenditures (C)}

The private consumption or consumer spending of a nation's economy is known as Personal Consumption Expenditures (C) (33). It is normally being grouped into three categories, which are long-lasting goods, non-durable goods, and services.

In the research study of Bhattacharya et al (34), they found that there are no significant effect between the consumption of energy and economic growth. However, when they revise their study, they detected that energy consumption are negatively impact the economic growth. Follow by the study of (35), they conclude that there is a positive relationship between energy consumption growth and the economic growth in the Philippines, but there is an inverse relationship found in the research study base in the Republic of Korea. Moreover, a two way causality between the growth of energy consumption and GDP growth were observed by (36), while (37) had found the impact of economic growth to the consumption of energy.

Overall, the previous research are very limited in study about the relationship between personal consumption and economic growth. The consumption of energy is also one of the categories of the personal consumption expenditures and the review of the previous research had shown a conflict result. Therefore, the future researcher may need to conduct more research about the relationship between consumption and economic growth as it is also a determinants of the GDP growth in a country.

\subsubsection{Gross Private Investment (I)}

Gross private investment is generally divided into two types, which are fixed investment and foreign direct investment. According to the economics experts, private investment are playing an important role in the long term stabilization, development and growth in developing countries (Borensztein, Gregorio \& Lee, 1998). There is a huge literature showing the positive impact Foreign direct investment (FDI) may had on economic growth (Hermes \& Lensink, 2003).

The study of (38) had analysed the impact of FDI on the economic growth in South Asian economies and he found a positive relationship between domestic investment, FDI, and GDP. The study could be concluded that the increase in FDI in South Asian countries mainly affected by low ownership restrictions and indeed he found that FDI contribution had foster the economic growth. However, (39) analysed the effect of FDI on economic growth in the case of Pakistan and she found a negative and insignificant relationship between GDP and FDI in Pakistan. This could be conclude that the lack of infrastructure and human resources in a country might reduce the FDI inflow and thus slow down the economic growth.

Similarly, (40) showed the results of negative correlation between FDI and domestic capital stocks (investment) in short run while in long run it became positive. Therefore, he conclude that the different duration of time period would yield different results of research. Moreover, (41) suggested that it is GDP that caused FDI in the case of Chile and not vice versa, while there were a strong evidence of a bi-directional causality between FDI and GDP for both Malaysia and Thailand.

Overall, the effect of FDI not only affect the level of output per capita but also affect economic growth rate. The previous research study had posed a various hypotheses to explain why FDI would potentially foster the growth rate of per capita income in the host country and affect the economic growth (Bengoa \& SanchezRobles, 2003).

\subsubsection{Government Expenditures (G)}

Government expenditures refers to the government spending on items that are "consumed" in the current period (42). The effect of government spending on the economic growth had been empirically studied and the conflicting results. Some of the studies found a negative relationship between government expenditures and economic growth, which supports the hypothesis that an increase in the government expenditure would slow down the economic growth. However, there are some of the studies found a positive relationship between government expenditure and economic growth, which support the hypothesis that rising government expenditure would foster the rising in economic growth. Moreover, there are still a few of the studies found no significant relationship between government expenditure and economic growth.

In the factual study by (43) found that the results showed a strong and persistent negative relationship between the types of government expenditures and the economic growth rate in the long run. He concludes that the rising in government expenditure is associated with a decline in economic growth. On the contrarily, (44) found a positive correlation between the government size and economic growth. This provides the evidence that the government expenditure would improve the private investment environment and thus lead to a higher economic growth. (45) had measured the impact of the growth rate of the government's share of consumption spending in GDP. They found that the type of government expenditure and the long-run economic growth has no any statistically significant relationship.

Overall, the studies conducted before attempt to determine the connection between the government expenditure and economic growth or between one or more of the types of government expenditure and economic growth had shown different results. The result showed is all depend on the model that used to study as well as the data used in the study. In addition, the different areas or countries that selected for studies would also be one of the main reasons that make the results differently.

\subsubsection{Net Exports (X-M)}

Net exports refers to a nations imports (M) minus exports (X). Imports are the goods and services produced outside the country and the residents purchased it, while exports are the goods and services produced domestically and sold to the foreigners (46). A fundamental issue for empirical research in international economics to what extent the export sector influences the growth of the economy as a whole (47).

According to (48), the results show a positive relationship between the exports and economic growth by using the Japanese data. This evidence supports the exports are playing the important role in foster the economic growth in Japan. Follow by the study from (49), which had found the evidence that the export-led growth hypothesis is supported and exports rising the demand of foreign exchange in order to purchased imports, which provides the further beneficial effects on economic growth. However, the study from (50) found that there are 65 out of 126 countries are supported the export-led growth hypothesis and the rest of the country found no significant relationship between exports and economic growth.

Overall, the research conducted to investigate the linkage between the net exports and economic growth or between the two types of exports and economic growth had yields the similar results, which 
are the positive relationship between the net exports and economic growth. Although the countries selected for studies and the method developed by previous researcher to conduct the research might be different, but base on the results showed it seems to be consistent for the exports as an important variable to foster economic growth.

\subsection{Inflation Rate}

Inflation rate refer as a rise in the general price level in the goods and services (19). The importance of determining the impact of the inflation on the performance of the banks, it is mainly due to the influence of inflation on the sources and uses of banks' financial resources (6). In the real world situation, inflation would definitely affect the companies' pricing behaviour, which the companies may believe that they could increase the prices of their goods and services without suffering the drop of the demand from their customers if they expect there would be a higher inflation in the future (51).

Moreover, (23) investigate the determinants that affected return on assets ratio by including the date from 80 countries for the time period of 1988-1995. They concluded the result that the inflation rate had affected the return on assets positively among the countries that selected for the research purpose. On the contrary, the research conducted by (52) determines the relationship between the macroeconomic factors and the return on assets ratio and return on equity ratio for a sample of Turkish banks for the time period of 2002-2007 by using the monthly data. They found the results that the profitability of the Turkish banks seems to had increased along with the decline of inflation rate, which means that it showed an inverse relationship between these two variables. Although the studies of (53) in Hong Kong and (54) in Malaysia had shown the positive relationship between the inflation rate and the bank's profitability, the study of (55), nevertheless, found a negative correlation between the inflation variable and banks' profitability, which show that the high inflation rate leads to reduce the bank profitability.

\subsubsection{Monetary Supply Growth}

Some of the researcher only investigate the relationship between money supply and economic growth without considering the impacts towards the inflation rate $(56,57)$. A comprehensive study about the relationship among money supply, economic growth, and inflation in Singapore, Malaysia and Indonesia were done by Masnan, Shaari, and Hussain (2013). They indicates that by simply looking at the effect of one of them is not sufficient government policy makers to formulate a policy for the adjustment of the inflation rate. They had found that is a direction relationship exists from money supply to inflation rate in Malaysia and Singapore. Thus, they summarize that the government should consider to control the money supply to influence economic growth because an increase in money supply could cause the rise in inflation instead of economic growth in Malaysia and Singapore.

\subsubsection{Exchange Rate Movement}

According to (58), since Saudi Arabia's oil policy could influence world oil prices and mostly depends on the imports of goods to meet domestic needs, a rise in world inflation would be transmitted to the Saudi economy through imported goods. This provides the evidence that the exchange rate movement would either increase or decrease the imported goods and then affects the inflation rate. Another research done by (59) found that the Purchasing Power Theory which illustrate the changes in the exchange rates in terms of differentials in inflation between countries, the inflation rate of the dominant country more likely to influence the inflation rate of smaller countries.

Moreover, (60) conduct a research base in Kenya and he observed that there is a positive relationship between exchange rate move- ment and the rate of inflation. Furthermore, a continuation of his study in the year of 1997 had developed an empirically error correction model, and found that the exchange rate had a long run effects on the inflation rate. Follow by the study of (61) that show the results of the exchange rate movements had explains the inflationary trend in most of the countries that studies. In addition, (62) in his research found that the expected inflation rate and relative price are positively correlated with Egypt's expected exchange rate. This could be conclude that the exchange rate movements would positively impacts the inflation rate.

Overall, all of the previous researcher showed a consistent results that indicates a positive relationship between inflation rates and exchange rate movements (58-62). A stable inflation rate must be desired by all of the countries and thus, the countries policy maker may need to formulate an appropriate exchange rate policy in order to maintain and adjust base on the inflation rate.

\subsection{Real Interest Rate}

Real interest rates is the differences between nominal interest rates and inflation (63). It is calculated by Fisher equation that we would discuss in the theoretical review part. Interest rate had an important role for any business to make profit and it is directly influences the bank's capital. According to Ali (2015), banks normally attract the capital by offering a higher interest rate to the current, savings and term deposit account. Therefore, when there is an increase in interest rate, savings would be more attractive than investments because the banks tends to pay more on saving accounts.

Follow by the study of Kasri and Kassim (2009) argued that, most of the banks would take some time in shaping up their interest rate on accounts and loans in order to maintain a balance between both of it and maximized profit. However, by focusing on increase in the interest rates, it would discourages the borrowings which results a high monthly payments incurred towards the depositors while the default on loan increases, which directly affect bank's profitability. Therefore, the higher the interest rate, the higher the bank's profitability through increase in the capital and lesser the borrowings. Moreover, (64) had examined the causal relationship between the conventional and Islamic banks in Malaysia. They concludes the results that consideration over interest rate is an important factor for Islamic banks before they adjust their return on deposits because it would directly affect the bank's profitability. In addition, determining the performance of the banks operating in thirteen EU banking markets. The result of the research show that the level of interest rate had a positive effect to the bank's profitability. (65) investigated the relationship between the Islamic bank financing and the macroeconomic variables in Malaysia. The result of the study show that Islamic bank financing is positively affected by the interest rate. They had also make the recommendation about that Malaysian Islamic banks may provide some products that are based on profit and loss sharing in order to increase the bank's profitability. In addition, to examine the growth of profitability for European banks between the year 2000 and the year2009. This study conclude that interest had a positive relationship with ROA and ROE of the European banking schemes, which means that the interest rate had a positive impact on the bank's profitability.

\subsection{Theory of Production - Bank Profitability}

According to (66), the process of production is a combination of factor inputs that required to produce every unit of output. The process of production shows the relationship between the factor inputs and the factor output (66), which means that a merchandise may be produced by various factors of production. As applied to this research study, the production theory holds the bank profitability as the factor outputs that would be affected by the macroeconomic determinants, which is the factor input. Therefore, there 
is a functional relationship between the bank profitability and the macroeconomic determinants (Kiganda, 2014).

\subsection{Classical Growth Theory - GDP Growth Rate}

The Classical growth theory argues that the economic growth would be ended because of the increasing of population and the limited resources. Classical theorists believed that the temporary increase in real GDP per person would cause the explosion of population, and thus reduce the real GDP as well. Adam Smith laid the foundation for Classical growth model that posited a supply-side driven model of growth. He viewed savings as the basis of investment and then growth. Therefore, in his point of view, how fast a nation can group can be seen from the income distribution of the nation.

Moreover, other economists developed an idea of a subsistence level to model this theory and it somehow sort like an equilibrium level that real GDP would always revert to the subsistence level. They believed that if real GDP raise upon this subsistence level of income, then it would cause the population to increase, and thus it would bring the real GDP back to the lower subsistence level. However, if the real GDP drop below this subsistence level of income, then it would cause the population to decrease, and thus real income would rise back to the subsistence level.

\subsection{Classical Theory of Inflation - Inflation Rate}

The classical theory of inflation holds the continuous increase in the price inflation that excessive growth in the quantity of money existence (67). Thus, it is also known as the Quantity Theory of Money, although it is not a theory of money but a theory of inflation (Ireland, 2014). The quantity theory of money describe the relationship between inflation and economic growth by summing the total amount of economy spending and total amount of money available in the market (Fountas, 2001).

(67) states that inflation is a monetary phenomenon that always and exist everywhere. He argued and challenged the concept of the Phillips Curve based on the premise of an economy where the cost of everything were doubles (68). In a simple words, individuals had to pay double for the price of goods and services, but they do not mind it just because their wages are also double. Therefore employment and output is not affected and the economists call this concept as the neutrality of money (Ireland, 2014).

\subsection{Fisher's Effect - Real interest Rate}

Irving Fisher introduce The Theory of Interest (1930) that cause the Fisher effect to become widely recognized and presented as a typical fact to the public. Fisher Effect is define as "The one for one relation between the inflation rate and nominal interest rate" (69), which means that for any 1 percent increase in the inflation rate would definitely causes the nominal interest rate to increase by 1 percent. The Fisher effect holds that the real interest rate equals to the expected inflation rate subtract from the nominal interest . Thus, the real interest rates would fall if the inflation rate were increases, unless the nominal rates were increase at the same as inflation rate. This is called as the Fisher equation, which it were playing an important role in the current finance and economics studies.

\section{Methodology}

In short, research framework is discuss about the interrelationships among the variables that are need to be conducted in this research study.

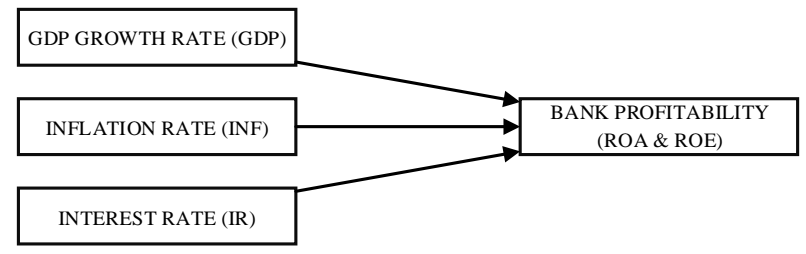

Fig. 3.1: Research Framework

\section{The Variables Description}

Table 3.1: Summary and Description of the Variables (Source: $(4,5)$.

\begin{tabular}{|c|c|c|c|}
\hline Symbol & Variables & Proxy & $\begin{array}{l}\text { Expected rela- } \\
\text { tion }(+/-)\end{array}$ \\
\hline \multicolumn{4}{|c|}{ Dependent Variables } \\
\hline ROA & $\begin{array}{l}\text { Return on } \\
\text { Assets }\end{array}$ & $\begin{array}{l}\text { Net Profit / Total } \\
\text { Assets }\end{array}$ & NA \\
\hline ROE & $\begin{array}{l}\text { Return on } \\
\text { Equity }\end{array}$ & $\begin{array}{l}\text { Net Profit / Common } \\
\text { Stock Equity }\end{array}$ & NA \\
\hline \multicolumn{4}{|c|}{ Independent Variables } \\
\hline GDP & $\begin{array}{l}\text { Economic } \\
\text { Growth }\end{array}$ & $\begin{array}{l}\text { GDP Growth rate } \\
\text { (annual \%) }\end{array}$ & $+/-$ \\
\hline INF & $\begin{array}{l}\text { Inflation } \\
\text { rate }\end{array}$ & $\begin{array}{l}\text { Inflation, Consumer } \\
\text { Price (annual \%) }\end{array}$ & $+/-$ \\
\hline IR & Interest rate & Real interest rate (\%) & $+/-$ \\
\hline
\end{tabular}

\subsection{Hypothesis Development}

\subsubsection{Annual GDP Growth Rate}

According to the research in Switzerland, (25) found the results that the GDP growth variable is the most important macroeconomic determinants, which had a positive impacts on the bank's profitability. However, there is another research study found that the bank's profitability are not significant affected by the economic growth (26). Therefore, after integrated the finding of several previous researcher, the hypothesis is form as below:

$\mathrm{H}_{0}$ : There is no significant relationship between annual GDP growth rate and bank's profitability.

$\mathrm{H}_{1}$ : There is a significant relationship between annual GDP growth rate and bank's profitability.

\subsubsection{Annual Inflation Rate}

According to (29), they had investigated the impact of bank characteristics as well as macroeconomic variables on the performance of the Macau Banking Industry that included 15 years data and the result concluded regard to macroeconomic variables, inflation rate are important as it posed a positive relation to the bank's profitability in Macau. On the contrary, the research conducted by (52) determines the relationship between the macroeconomic factors and the return on assets ratio and return on equity ratio for a sample of Turkish banks for the time period of 2002-2007 by using the monthly data. They found the results that the profitability of the Turkish banks seems to had increased along with the decline of inflation rate, which means that it showed an inverse relationship between these two variables. Therefore, after integrated the finding of several previous researcher, the hypothesis is form as below:

$\mathrm{H}_{0}$ : There is no significant relationship between annual inflation rate and bank's profitability.

$\mathrm{H}_{1}$ : There is a significant relationship between annual inflation rate and bank's profitability.

\subsubsection{Real Interest Rate}

According to the research in thirteen EU banking markets, (70) determine the factors affect the performance of the banks and the result of the research show that the level of interest rate had a positive effect to the bank's profitability. In addition, it is investi- 
gate the bank specific and macroeconomic factors of the bank's profitability in Turkey over the time period from the year 2002 to 2010 and they also found that interest rate is the only factors that affect the performance of bank positively among the macroeconomic factors. Therefore, after integrated the finding of several previous researcher, the hypothesis is form as below:

$\mathrm{H}_{0}$ : There is no significant relationship between real interest rate and bank's profitability.

$\mathrm{H}_{1}$ : There is a significant relationship between real interest rate and bank's profitability.

This research study is mainly determine the relationship between macroeconomic determinants and foreign bank's profitability. The secondary analysis mainly focused on the existing data collected from the bank's official website and World Bank Group and narrow down the research direction in order to relate to the research interest. Sampling size is refers to the number of observations that studied in a sample. In this research study, ten foreign banks in Malaysia are randomly selected from the year 2006 to 2015 , which had a total sample size of 100 .

The objective of this research study is to determine the relationship between macroeconomic determinants and foreign bank's profitability in Malaysia. Thus, the target population of this research study is set to be the foreign banks in Malaysia. Malaysia had a population of 27 commercial banks, which there are 8 local banks among them and the remaining are the foreign banks. Thus, ten foreign banks were randomly chosen as a sample in order to conduct this research study. The following

This research study investigated the relationship between profitability of foreign banks and macroeconomic determinants in $\mathrm{Ma}-$ laysia for the period of year 2006 to year 2015. The financial statements were retrieved from each of the bank's official website and the data of the macroeconomic determinants are retrieve from the World Bank Group.

In order to conduct a quantitative research, secondary data is being used in order to obtain a necessary information. According to (71), secondary data is refers to the information that could be obtained from the research articles, books, and journals. In this research study, the data that had been used were obtained from the annual report of the selected foreign banks in Malaysia and also from the World Bank Group. All of the annual reports were downloaded from each of the bank's official website and the data were extracted and computed from the income statement, balance sheet, statement of changes in equity and also notes to account. However, with regard to the macroeconomic variables, the data of annual GDP growth rate, annual inflation rate and real interest rate would be obtained from the statistic that officially published by the World Bank Group. The time frame for this research study and the data collected were 10 years' time, which from the year 2006 to the year 2015. In addition, the journals and article that use as the references and literature review are gathered and obtained from the Google Scholar and also Siti Hadmah Digital Library Database, where there are several links are given by Multimedia University to ease the student to search the related journal and books.

\section{Findings}

Descriptive statistics analysis of all data variables for ranges from 2006 to 2015. Mean is the average of all the variables which are included in this study for given set of data and it is calculated as the total of all observations divided by the number of observations. It is often read and analyze together with the standard deviation, where mean describes the data central location, and the standard deviation describe the spread. The greater the standard deviation, the greater the spread of the range of values within the sample. The mean and median for the ROA are 0.0103655 and 0.0115515 respectively for the Malaysia's foreign banks for the study period undertaken. Minimum value is -0.00540 and 0.02407 is the maximum value in the data set. The data set had the standard deviation of 0.00497952 which is the lowest among all the variables. A low standard deviation shows that the data of ROA are closely around the mean, which means that the data is more reliable.

On the other hand, GDP shows both the highest mean and median value among all the variables, which equal to 4.92300 and 5.38400 respectively. Minimum value is -2.526 and 9.428 is the maximum value in the data set. The standard deviation of GDP is 2.925127, which is the second higher among all the variables. A high standard deviation shows that the data of GDP is widely spread, which means that the data is less reliable. This is due to the fact that the GDP had a significant movement from the year 2006 until 2015 in Malaysia.

Followed by the inflation rate, the values of mean and median is equal to 2.55770 and 2.10450 respectively. 5.441 is the maximum value in the show in the above table and 0.583 is the minimum value in the study period undertaken. Standard deviation had shown a value equal to 1.283111 , which is about double the value of mean, which indicates that the data set of inflation rate is highly dispersed from mean. This is due to the fact that the inflation rate had a significant movement throughout the study period in Malaysia.

The mean and median for real interest rate are 2.44300 and 3.07900 respectively for the year 2006 until year 2015 in Malaysia Real interest rate show a minimum value equal to -5.289 and 10.633 is maximum value. The minimum value of real interest rate is the lowest and the maximum value of real interest rate is the highest among all the variables. The data set of real interest rate had shown standard deviation of 4.218395 , which is also the highest among all the variables. A high standard deviation shows that the data of real interest rate is widely spread, and it is due to the fact that the real interest rate had a significant movement from the year 2006 until 2015 in Malaysia.

\subsection{Pearson Correlation Coefficient}

Pearson correlation coefficient is a test that commonly used by the researcher to determine the degree of the relationship between the variables used (72). For this research study, aims to determine the correlation between the dependent variable, Return on Assets and three independent variables, which are GDP growth rate (GDP), Inflation rate (INF) and Real interest rate (IR) by apply the Pearson correlation coefficient.

It proposed that the rules of thumb about correlation are determined by the strength of the associate which is the significant level. The Pearson correlation coefficient is denoted as $r$ value. If the $\mathrm{r}$ value is exactly 1 , which means there is a perfect positive linear relationship, however a $-1 \mathrm{r}$ value show a perfect negative linear relationship. On the other hand, for the $r$ value of 0.70 show a strong and positive linear relationship, but the -0.70 show a strong and negative linear relationship. Same goes to 0.50 and 0.30 of $\mathrm{r}$ value shows a moderate and weak positive linear relationship, while -0.50 and -0.30 of $\mathrm{r}$ value shows a moderate and weak negative linear relationship. Follow by the $r$ value of 0 shows that there is no linear relationship of both variables.

The GDP is significant at 0.646 with a correlation coefficient of 0.046 , which means there is a weak correlation between GDP and ROA as the value of $r$ fall on the weak correlation range. Since the value of $r$ is negative, Pearson correlation coefficient shows that GDP had a negative correlation with ROA. GDP is also significant at 0.646

The Inflation rate is significant at 0.001 with a correlation coefficient of 0.324 , which means there is a moderate correlation between Inflation rate and ROA as the value of $r$ fall on the moderate correlation range. Since the value of $r$ is positive, Pearson correlation coefficient shows that Inflation rate had a positive correlation with ROA.

According to the real interest rate is significant at 0.032 with a correlation coefficient of -0.215 , which means there is a weak correlation between Real interest rate and ROA as the value of $r$ fall on the little correlation range. Since the value of $r$ is negative, 
Pearson correlation coefficient shows that real interest rate had a negative correlation with ROA.

\subsection{Sargan Test}

The Sargan test is use to test the validity of the instrumental variables that use in the research study. It is also a test that use to determine the over identifying restrictions for the Generalized Method of Moments Estimators.

The result of Sargan test for this research study. The value of 0.9999999581459032 is approximate 1.0, which show that every variables use in this research study are very strong and valid instrument variables.

\subsection{Panel Generalized Method of Moments (GMM)}

Table 3: Panel Generalized Method of Moments (GMM) Statistics

\begin{tabular}{|c|c|c|c|c|}
\hline Variable & Coefficient & Std. Error & t-Statistic & Prob. \\
\hline $\mathrm{ROA}(-1)$ & -0.134427 & 0.064137 & -2.095933 & 0.0394 \\
\hline GDP & 0.004599 & 0.001866 & 2.465433 & 0.0159 \\
\hline IR & 0.000198 & $5.19 \mathrm{E}-05$ & 3.818264 & 0.0003 \\
\hline INF & 0.001084 & $9.92 \mathrm{E}-05$ & 10.93605 & 0.0000 \\
\hline & \multicolumn{2}{|c|}{ Effects Specification } & & \\
\hline \multicolumn{4}{|c|}{ Cross-section fixed (first differences) } & \\
\hline $\begin{array}{l}\text { Mean dependent } \\
\text { var }\end{array}$ & -0.000398 & \multicolumn{2}{|c|}{ S.D. dependent var } & 0.017340 \\
\hline S.E. of regression & 0.016563 & \multicolumn{2}{|c|}{ Sum squared resid } & 0.020848 \\
\hline J-statistic & 8.942275 & \multicolumn{2}{|c|}{ Instrument rank } & 10 \\
\hline Prob(J-statistic) & 0.176851 & & & \\
\hline
\end{tabular}

The model of the study is stated as below:

$\boldsymbol{R O A} A_{i t}=\beta_{0}+\beta_{1} G D P_{i t}+\beta_{2} I N F_{i t}+\beta_{3} R I_{i t}+v_{i}+\Omega_{t}+u_{i t}$ (Where $\beta_{0}=$ constant; $\beta_{1-3}=$ coefficient of independent variables)

Based on the GMM result, the model is developed as below:

\subsection{Real Interest Rate}

$\mathrm{H}_{0}$ : There is no significant relationship between real interest rate and bank's profitability.

$\mathrm{H}_{1}$ : There is a significant relationship between real interest rate and bank's profitability.

Since $\mathrm{p}$ value $=0.000<0.05$, reject $H_{O}$ and conclude that there is a significant relationship between real interest rate and return on assets. Moreover, the positive $\mathrm{p}$ value implies the positive relationship between real interest rate and bank's profitability, which means the increase in real interest rate generally been associated with greater profitability generated by the bank. This empirical findings provided support to the previous studies conducted by $(65$ 73-77).

\section{Conclusion}

The purpose of this research study is to determine the macroeconomic determinants that would impact the foreign bank's profitability in Malaysia. There are 10 out of 19 foreign banks in Malaysia that had been selected for this research study from 2006 to 2015. All of the independent variables includes GDP, Inflation rate, and real interest rate is determine to be positive and significant to the dependent variables, which is bank's profitability (ROA). Throughout this chapter, the findings of this research study is found to be fulfilled the research objectives that we had proposed in the earlier part. Furthermore, there are also some of the limitations that could affect the result of this research study, which included the limitation of the research time period, the limitation of independent variables and the time constraints. The recommendation for the future researcher also provided in this research study, which include lengthened the period of study, increase the span of study and also include other important independent variables which may improve the completeness of this research topic.

\section{$R O A_{\text {it }}=-0.134427+0.004599 G D P_{\text {it }}+0.000198 I N F_{\text {it }}+0.0001084 R I_{\text {it }}$}

\subsection{GDP}

$\mathrm{H}_{0}$ : There is no significant relationship between GDP and bank's profitability.

$\mathrm{H}_{1}$ : There is a significant relationship between GDP and bank's profitability.

Since $\mathrm{p}$ value $=0.0159<0.05$, reject $\mathrm{H}_{0}$ and conclude that there is a significant relationship between GDP and return on assets. Moreover, the positive $\mathrm{p}$ value implies the positive relationship between GDP growth and bank's profitability, which means the greater the GDP growth generally been associated with greater profitability generated by the bank. This empirical findings provided support to the previous studies conducted by $(6,9,17,18$, $23-25,28,31,32)$.

\subsection{Inflation Rate}

$\mathrm{H}_{0}$ : There is no significant relationship between inflation rate and bank's profitability.

$\mathrm{H}_{1}$ : There is a significant relationship between inflation rate and bank's profitability.

Since $\mathrm{p}$ value $=0.0003<0.05$, reject $H_{o}$ and conclude that there is a significant relationship between inflation rate and return on assets. Furthermore, the positive $\mathrm{p}$ value implies the positive relationship between inflation rate and bank's profitability, which means that the greater the inflation rate generally lead to a greater profitability for the banks. This empirical findings provided support to the previous studies conducted by Athanasoglou, (9, 23, 29, $31,53,54,70)$
[1] Chin SL, Gan HY, Heng KL, Lim PK, Soo JY. Economic factors affecting performance of foreign banks in Malaysia: UTAR; 2013.

[2] Demirgüç-Kunt A, Huizinga $\mathrm{H}$, Claessens $\mathrm{S}$. How does foreign entry affect the domestic banking market? 1998.

[3] Hermes CLM, Lensink BW. The impact of foreign bank entry on domestic banking markets: A note: University of Groningen; 2001.

[4] Anbar A, Alper D. Bank specific and macroeconomic determinants of commercial bank profitability: Empirical evidence from Turkey. 2011.

[5] Sufian F. Profitability of the Korean banking sector: Panel evidence on bank-specific and macroeconomic determinants. Journal of economics and management. 2011;7(1):43-72

[6] Gul S, Irshad F, Zaman K. Factors Affecting Bank Profitability in Pakistan. Romanian Economic Journal. 2011;14(39).

[7] Elyor S. Factors affecting the performance of foreign banks in Malaysia: Universiti Utara Malaysia; 2009.

[8] Miller SR, Parkhe A. Is there a liability of foreignness in global banking? An empirical test of banks' X-efficiency. Strategic management journal. 2002;23(1):55-75

[9] Adeusi SO, Kolapo FT, Aluko AO. DETERMINANTS OF COMMERCIAL BANKS'PROFITABILITY PANEL EVIDENCE FROM NIGERIA. 2014

[10] Levine R. Foreign banks, financial development, and economic growth. International financial markets: Harmonization versus competition. 1996; 7:224-54.

[11] Gelb AH, Sagari SB. Trade in banking services: issues for multilateral negotiations: World Bank Publications; 1990.

[12] Stiglitz JE. The role of the state in financial markets. The World Bank Economic Review. 1993;7(suppl_1):19-52.

[13] Claessens S, Demirgüç-Kunt A, Huizinga H. How does foreign entry affect domestic banking markets? Journal of Banking \& Finance. 2001;25(5):891-911. 
[14] Mahajan A, Rangan N, Zardkoohi A. Cost structures in multinational and domestic banking. Journal of Banking \& Finance. 1996;20(2):283-306.

[15] Hasan I, Hunter WC. Efficiency of Japanese multinational banks in the United States. Research in finance. 1996;14:157-74.

[16] Berger AN, DeYoung R, Genay H, Udell GF. Globalization of financial institutions: Evidence from cross-border banking performance. Brookings-Wharton papers on financial services. 2000;2000(1):23-120.

[17] Flamini V, Schumacher ML, McDonald MCA. The determinants of commercial bank profitability in Sub-Saharan Africa: International Monetary Fund; 2009

[18] Sufian F, Habibullah MS. Bank specific and macroeconomic determinants of bank profitability: Empirical evidence from the China banking sector. Frontiers of Economics in China 2009;4(2):274-91

[19] Naceur SB. The determinants of the Tunisian banking industry profitability: Panel evidence. Universite Libre de Tunis working papers. 2003:1-17.

[20] Alkassim FA. The profitability of Islamic and conventional banking in the GCC countries: A comparative study. Journal of Review of Islamic Economics. 2005;13(1):5-30.

[21] Athanasoglou PP, Brissimis SN, Delis MD. Bank-specific, industry-specific and macroeconomic determinants of bank profitability. Journal of international financial Markets, Institutions and Money. 2008;18(2):121-36.

[22] Goddard JA, Molyneux P, Wilson JO. Dynamics of growth and profitability in banking. Journal of Money, Credit, and Banking. 2004;36(6):1069-90

[23] Demirgüç-Kunt A, Huizinga H. Determinants of commercial bank interest margins and profitability: some international evidence. The World Bank Economic Review. 1999;13(2):379-408.

[24] Bikker JA, Hu H. Cyclical patterns in profits, provisioning and lending of banks and procyclicality of the new Basel capital requirements. Banca Nazionale del Lavoro Quarterly Review. 2002;55(221):143.

[25] Dietrich A, Wanzenried G, editors. What determines the profitability of commercial banks? New evidence from Switzerland. 12th Conference of the Swiss Society for Financial Market Researches, Geneva; 2009.

[26] Athanasoglou P, Delis M, Staikouras C. Determinants of bank profitability in the South Eastern European region. 2006.

[27] Petria N, Capraru B, Ihnatov I. Determinants of banks' profitability: evidence from EU 27 banking systems. Procedia Economics and Finance. 2015;20:518-24.

[28] Lindsey CW. Firm size and profit rate in Philippine Manufacturing. The Journal of Developing Areas. 1981;15(3):445-56.

[29] Vong PI, Chan HS. Determinants of bank profitability in Macao Macau Monetary Research Bulletin. 2009;12(6):93-113.

[30] Aminu M, Okachi EE, Abubakar SM, Yahaya A. Prevalence of hepatitis B virus surface antigen among healthy asymptomatic students in a Nigerian University. Annals of African medicine. 2013;12(1):55

[31] Sufian F, Chong RR. Determinants of bank profitability in a developing economy: empirical evidence from the Philippines. Asian Academy of Management Journal of Accounting \& Finance. 2008;4(2)

[32] Pasiouras F, Kosmidou K. Factors influencing the profitability of domestic and foreign commercial banks in the European Union. Research in International Business and Finance. 2007;21(2):222-37.

[33] Stiglitz J, Sen A, Fitoussi J-P. The measurement of economic performance and social progress revisited. Reflections and overview Commission on the Measurement of Economic Performance and Social Progress, Paris. 2009.

[34] Bhattacharya M, Paramati SR, Ozturk I, Bhattacharya S. The effect of renewable energy consumption on economic growth: Evidence from top 38 countries. Applied Energy. 2016;162:733-41.

[35] Hong Y, Yu J, Chai K. Effects of drought stress on major upland crops. Research Reports-Rural Development Administration (Korea R). 1985.

[36] Hwang DB, Gum B. The causal relationship between energy and GNP: the case of Taiwan. The Journal of Energy and Development. 1991:219-26.

[37] Cheng BS, Lai TW. An investigation of co-integration and causality between energy consumption and economic activity in Taiwan. Energy economics. 1997;19(4):435-44.
[38] Agarwal R, Karahanna E. Time flies when you're having fun: Cognitive absorption and beliefs about information technology usage. MIS quarterly. 2000:665-94.

[39] Falki N. Impact of foreign direct investment on economic growth in Pakistan. International Review of Business Research Papers. 2009;5(5):110-20.

[40] Khan MA. Foreign direct investment and economic growth: the role of domestic financial sector. Pakistan Institute of Development Economics, 2007.

[41] Chowdhury A, Mavrotas G. Growth: What Causes What?'. World Economy. 2006;29(1).

[42] Romer CD, Romer DH. The macroeconomic effects of tax changes: estimates based on a new measure of fiscal shocks. American Economic Review. 2010;100(3):763-801.

[43] Landau D. Government expenditure and economic growth: a crosscountry study. Southern Economic Journal. 1983:783-92.

[44] Ram R. Government size and economic growth: A new framework and some evidence from cross-section and time-series data. The American Economic Review. 1986;76(1):191-203.

[45] Kormendi RC, Meguire PG. Macroeconomic determinants of growth: cross-country evidence. Journal of Monetary economics. 1985;16(2):141-63.

[46] Granger CW. Investigating causal relations by econometric models and cross-spectral methods. Econometrica: Journal of the Econometric Society. 1969:424-38.

[47] Neev D, Emery KO. The Dead Sea. 1967.

[48] $\mathrm{Xu}$ Z. Export and income growth in Japan and Taiwan. Review of International Economics. 1998;6(2):220-33

[49] Thirlwall AP. Trade, trade liberalisation and economic growth: theory and evidence: African Development Bank; 2000.

[50] Riezman RG, Summers PM, Whiteman CH. The Engine of Growth or its Handmaiden? A Time-Series Assessment of Export-led Growth University of Iowa Department of Economics Working Paper Series. 1995:95-16

[51] Driver R. Public attitudes to inflation and interest rates. 2007.

[52] Sayilgan G, Yildirim O. Determinants of profitability in Turkish banking sector: 2002-2007. International Research Journal of Finance and Economics. 2009;28:207-14.

[53] Jiang G, Tang N, Law E, Sze A. Determinants of Bank Profitability in Hong Kong, Hong Kong Monetary Authority Research Memorandum, September. 2003.

[54] Guru BK, Staunton J, Balashanmugam B. Determinants of commercial bank profitability in Malaysia. Journal of Money, Credit, and Banking. 2002;17(1):69-82.

[55] Atasoy H. Expenditure-income analysis in turkish banking sector and determinants of profitability. Unpublished Dissertations of Senior Specialists, Central Bank of Turkey, Ankara. 2007.

[56] Ogunmuyiwa M, Ekone AF. Money supply-Economic growth nexus in Nigeria. Journal of Social Sciences. 2010;22(3):199-204.

[57] Magazzino C. Disaggregated public spending, GDP and money supply: Evidence for Italy. 2011.

[58] Aleisa EA. Essays on macroeconomic fluctuations, oil prices, and world inflation: The case of Saudi Arabia. 2003.

[59] Cassel G. Further observations on the world's monetary problem. The Economic Journal. 1920;30(117):39-45.

[60] Peterson S, Kinyeki C, Mutai J, Ndungu C. Computerizing Accounting Systems in Developing Bureaucracies: Lessons from Kenya. Public Budgeting \& Finance. 1996;16(4):45-58.

[61] Canetti E. Monetary growth and exchange rate depreciation as causes of inflation in African countries: An empirical analysis. 1991.

[62] Issawi C. EGYPT IN REVOLUTION AN ECONOMIC ANALYSIS1963.

[63] Samuelson PA. The effect of interest rate increases on the banking system. The American economic review. 1945;35(1):16-27.

[64] Abduh M, Idrees Y. Determinants of Islamic banking profitability in Malaysia. Australian Journal of Basic and Applied Sciences. 2013;7(2):204-10

[65] Adebola SS, Yusoff WSW, Dahalan J. The impact of macroeconomic variables on Islamic banks financing in Malaysia. Research Journal of Finance and Accounting. 2011;2(4):22-32.

[66] Koutsoyiannis D. Climate change, the Hurst phenomenon, and hydrological statistics. Hydrological Sciences Journal. 2003;48(1):3-24

[67] Friedman M. Nobel lecture: inflation and unemployment. Journal of political economy. 1977;85(3):451-72.

[68] Gokal V, Hanif S. Relationship between inflation and economic growth: Economics Department, Reserve Bank of Fiji; 2004. 
[69] Mankiw NG, Weinzierl M. The optimal taxation of height: A case study of utilitarian income redistribution. American Economic Journal: Economic Policy. 2010;2(1):155-76.

[70] Smith R, Staikouras C, Wood G. Non-interest income and total income stability. 2003.

[71] Mugenda M, Mugenda A. Research methods in education Quantitative and qualitative approach, Nairobi. Acts press; 2003.

[72] Rahman MM, Hamid MK, Khan MAM. Determinants of bank profitability: Empirical evidence from Bangladesh. International journal of business and management. 2015;10(8):135.

[73] Ali M. Macroeconomic Determinants of Islamic Banks Profitability in Pakistan: a time series analysis. Journal of Business Strategies. 2015;9(2):83.

[74] Kasri R, Kassim SH. Empirical determinants of saving in the Islamic banks: Evidence from Indonesia. 2009.

[75] Wood B. Nicol, 1.(1972). Rat control on oil palm estates. Advances in oil palm cultivation, Wastie, RL and Earp, DA (Eds), Kuala Lumpur, Incorp Soc Plrs.380-95.

[76] Bourke P. Concentration and other determinants of bank profitability in Europe, North America and Australia. Journal of Banking \& Finance. 1989;13(1):65-79.

[77] Homoud SH. Progress of Islamic banking: the aspirations and the realities. Islamic Economic Studies. 1994;2(1):71-80. 